\title{
Assistance to students in mastering skills to resist the influence of destructive online communities
}

\section{Asistencia a estudiantes en el dominio de habilidades para resistir la influencia de comunidades destructivas en línea}

\author{
BELOUSOVA, Natalya A. ${ }^{1}$ \\ KORCHEMKINA, Yuliya V. ${ }^{2}$ \\ STERLIGOVA, Ekaterina A. ${ }^{3}$ \\ FORTYGINA, Svetlana N. ${ }^{4}$ \\ PAVLOVA, Larisa N. ${ }^{5}$
}

\begin{abstract}
The article presents the results of the impact of the Internet and virtual network communities on students. The main research method was the questionnaire of the international research project of the London School of Economics and Political Science (LSE), the UNICEF-Innocenti Research Bureau and the EU Kids Online network - Global Kids Online. The authors propose a solution to the problem of the effects of destructive Internet communities on students through the creation of a communicative field for successful socialization of students.

Keywords: student, destructive online communities, internet addiction.

Resumen

El artículo presenta los resultados del impacto de Internet y las comunidades de redes virtuales entre los estudiantes. El principal método de investigación fue el cuestionario del proyecto de investigación internacional de la London School of Economics and Political Science (LSE), el UNICEF-Innocenti Research Bureau y la red EU Kids Online - Global Kids Online. Los autores proponen una solución al problema de los efectos de las comunidades destructivas de Internet en los estudiantes mediante la creación de un campo comunicativo para la socialización exitosa de los estudiantes.

Palabras clave: estudiante, comunidades destructivas en línea, adicción a internet.
\end{abstract}

\footnotetext{
${ }^{1}$ Department of Mathematics, Natural Science and Methods of Teaching Mathematics and Natural Science,South Ural State Humanitarian Pedagogical University, Chelyabinsk,Doctor of Pedagogical SciencesProfessor. Contact e-mail: belousova@cspu.ru

${ }^{2}$ Department of Mathematics, Natural Science and Methods of Teaching Mathematics and Natural Science, South Ural State Humanitarian Pedagogical University, Chelyabinsk, Senior lecture. Contact e-mail: korchemkinayuv@cspu.ru

${ }^{3}$ Department of English Philology,South Ural State Humanitarian Pedagogical University, Chelyabinsk.Assistant . Contact e-mail: katerinasterligova13@gmail.com

${ }^{4}$ Department of Pedagogy, Psychology and Subject Methods, South Ural State Humanitarian Pedagogical University, Chelyabinsk. Candidate of Pedagogical Sciences, Associate Professor. Contact e-mail:fortyginasn@cspu.ru

5 Department of training teachers of vocational training and subject methods. South Ural State Humanitarian Pedagogical University, Chelyabinsk. Candidate of Pedagogical Sciences, Associate Professor. Contact e-mail: pavlovaln@cspu.ru
} 


\section{Introduction}

The theoretical basis for studying the impact of the Internet on students was research carried out under the auspices of UNESCO, according to which children from all over the world are at risk through the impact of the Internet and other new media (Child Safety Online. Global challenges and strategies, 2012).

With the advent of e-mail, social networks, blogs, chat lines, game and digital cameras, students expand their opportunities for communication, and increase the speed and frequency of access to interaction. According to a study by Kaspersky Lab, almost $43 \%$ of younger students are registered on social networks, while in the senior echelon this indicator increases to $95 \%$. Along with this, $50 \%$ of schoolchildren answered that social networks choose to meet new people, $30 \%$ of schoolchildren admitted that they met with people from social networks (Adults and children in the digital world: when online meets offline, 2019) .

The psychological dependence of students on the use of online communities is an urgent problem of modern education. This problem is determined by the lack of attention on the part of the teacher working with the student and his family to develop their ability to withstand the influences of destructive Internet communities.

The main aspects of the phenomenon of Internet communities were considered in domestic studies by BoltagE.Yu., Bondarenko S.V., Duzhnikova A.S., Konchakovsky R.V., Rozina I.N., Sergodeeva V.A., Silaeva V.L. ., Skuratova A.B., Toiskina V.S., Shakhmartova O.M., in foreign studies are reflected in the works of TimmonsMitchell et al., (2016).They formulated the main characteristics of Internet communities, highlighted the criteria and described evaluation tools for identifying Internet addiction. The results of their research largely determine the current state of the problem and serve as the basis for many professional practitioners to implement a set of preventive measures.

Under the Internet community, it is customary to understand a special type of social association of users of communication networks, the integration of which arises on the basis of a common discourse in the virtual space with long-term and emotional involvement in the communication process (Sergodeev, 2013). Considering online communities, some foreign authors note that more often signs of Internet addiction appear in children due to the weak activity of the frontal lobes of the cerebral cortex, responsible for decision-making and control impulsive behavior (Ferranti, 2016 and Kardaras, 2016).

Of course, changes in the state of the brain structure of children, in particular during adolescence, are part of the normal development process and are not always evidence of the development of Internet addiction. However, an analysis of foreign studies in neurobiology showed that some researchers, relying on the dopamine theory of addiction, believe that increased dopamine release in children can be caused by the influence of modern information technologies (Nutt et al., 2015). Dopamine is an active chemical produced by the human brain that is responsible for motivation, reward, and stimulating behavior (Di Chiara and Imperato, 1988).

The assertion about the influence of information technology on the production of dopamine associated with control systems and impulsivity gained wide popularity in the media and in scientific research. Modern information technologies cause a feeling of pleasure, which is not always amenable to control, which leads to addiction. The schoolchildren's repeated use of modern information technologies causes a feeling of dependence, which is provoked by the nerve cells of the prefrontal cortex, which is responsible for planning and decision-making. The associativity between addiction and pleasure is determined by the system of motivation to action in order to find a source for pleasure, which can be information technology.

However, this statement has lost its relevance over time in connection with the presentation of research results by generalized American scientists (Nutt et al.,2015) over the past 40 years on the dopamine theory of dependence. Analysis of studies has shown that there is a more complex relationship between dopamine and 
addiction than the authors of the dopamine addiction theory describe. The results of research by American scientists described in "The dopamine theory of addiction: 40 years of highs and lows" refute previously put forward positions, believing that the release of dopamine is a natural pattern of the normal functioning of the brain, which affects attention, memory, motivational significance and motor activity. The research results refute the fact that the release of dopamine and a sense of success cause dependence on the use of modern information technologies, and vice versa, dopamine can play an important role in building resistance against dependence on certain substances.

The results of studies by American neuroscientists only confirm that the influence of information technology does not lead to dependence on direct effects on the brain. The question of the relationship between brain structure and behavior is still poorly understood.

\section{Methodology}

As a tool for studying the impact of the Internet and virtual network communities on students, a questionnaire was used by the international research project of the London School of Economics and Political Science (LSE), the UNICEF-Innocenti Research Bureau and the EU Kids Online - Global Kids Online. The questionnaire includes 18 modules that have been adapted for Russian-speaking students.

The questionnaire consists of the following modules (Global kids online research toolkit, 2020):

A. Child identity (module of the survey includes questions children's demographic (age, gender, etc.) and socioeconomic background, some psychological characteristics, health and able-bodiedness, and further measures of children's capacities, experiences or vulnerabilities).

B. Access (module seeks to explore and measure the growing complexities of online presence and participation by accounting for the diverse locations where children may go online, the multiplicity of devices they use, and the varying levels of access afforded in their country/area).

C. Well-being (benefits) (module seeks to explore the extent to which children experience the internet as a positive environment - whether they are having a good time online, whether the internet offers good things for children to do, children's perception of the most important advantages it offers).

D. Activities (opportunities) (module explores the full range of children's online practices related to learning, community and civic participation, creativity, social relationships and online communication, entertainment, personal and commercial use, e-health).

E. Communication (module includes issues related to children's use of websites or apps, their approach to online communication, behaviour and safety on social networking sites).

F. Skills (module covers operational skills, informational/browsingskills, social skills, creative skills and skills related to mobile devices).

G. Well-being (harms) (module offers questions on excessive internet use).

H. Activities (risks)(This module covers different types of online experiences that may put children at risk, such as meeting new people online, being treated or treating others in a hurtful way, exposure to sexual content (voluntary and involuntary), excessive internet use, and risky online opportunities, as well as the possible connections to risks experienced offline (whether face-to-face or via traditional media). 
I. Communication (sexual)(This module covers different types of sexual communication including witnessing, receiving and sending sexual messages, motivation for sending sexual images, and feelings and coping behaviour about those experiences).

J. Sexual exploitation and abuse (the module includes a series of questions exploring unwanted exposure and harm, as well as the need to assess, rather than assume, harm from such exposure).

K. Hurtful and bullying behavior (The module distinguishes between the different roles children can play in relation to risky online content - as receivers, participants and actors - and explores children's feelings and coping behaviour about those experiences).

L. Social support (It includes questions on the child's relationship with their parents, whether the child feels supported and safe at home, at school or in their community. The module includes questions on children's overall feelings about school life - belonging, being supported, school performance, the pressure of doing school work).

M. Education (In this module, the focus is on how children use digital technology for learning at school and home).

$\mathrm{N}$. Internet mediation (this module offers questions on the ways peers mediate online experiences and also how they might generally support and help the particular child).

O. Well-being (the survey focuses on its economic (e.g., socio-economic status, availability of basic necessities, noting that these vary across countries), emotional (happiness, self-efficacy) and social elements (support from family, peers, educators and the community).

P. Privacy (This module allows the assessment on both perception of privacy risks and actual privacy-protection behaviours).

Q. Parent module (These include access (frequency of use, places and devices, barriers to use), skills (the full range of digital skills), parental mediation, parental perception of the child's online risk and harm, sources of information about the internet, and a range of questions about the child and family's background including household income, parental education and employment status, religiousness, and child disability).

R. Teacher module (The questions cover teachers' internet use, use of technology for teaching, digital skills, mediation and monitoring of students, sources of information for how to help children and keep them safe online).

\section{Results}

In the process of research, we obtained the following results of the impact of the Internet and virtual network communities on students. The group of subjects was assembled from among the students of the school MBOU "Secondary School No. 19 of Chelyabinsk", in the amount of 342 people, the age of the subjects was 8-17 years. The purpose of the study involves the construction of the following tasks: to determine the nature of leisure activities of students using the questionnaire; identify among the tested students a group of students who are subject to the influence of destructive online communities.

In the course of the study, 342 students of the school MBOU "Secondary school No. 19 of Chelyabinsk" were interviewed. Define the composition of respondents by gender. 
Figure 1

The division of students of MBOU "Secondary

school No. 19 of Chelyabinsk" by gender

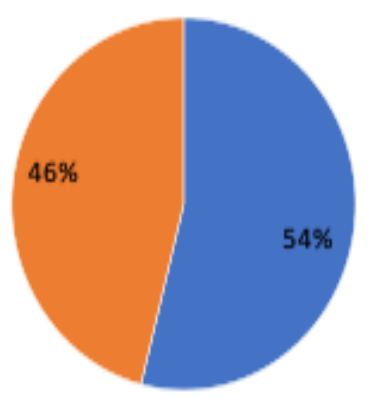

- Female

Male

Source: authors

According to fig. 1 it can be seen that among the respondents girls predominate, their share is $54 \%$ ( 185 people), and boys - $46 \%$ (157 people).

Among the respondents, the following age categories of students of MBOU "Secondary School No. 19 of Chelyabinsk" were presented:

Figura 2

The division of students of MBOU "Secondary school No. 19 of Chelyabinsk" by age

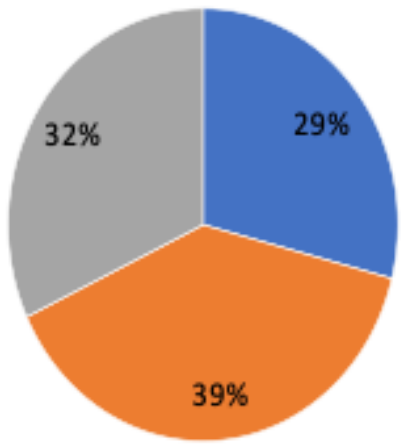

= 8 - 10 years

" $11-13$ years

II $15-18$ years

Source: authors

According to Fig. 2. it can be seen that the majority of students aged 11 to 13 years - 39\% (133 people), 32\% (109 people) under the age of 18 years, and the smallest number of students - 29\% (100 people) aged 8 up to 10 years.

Using the questionnaire, we determined the nature of the students' leisure activities. To this end, we interviewed students and obtained the following results that students spend more time playing computer games. The percentage of students visiting social networks, of the total number of children was $23 \%$. This figure is quitehigh. 
Figura 3

The main types of leisure activities of students of MBOU "Secondary school No. 19 of Chelyabinsk"

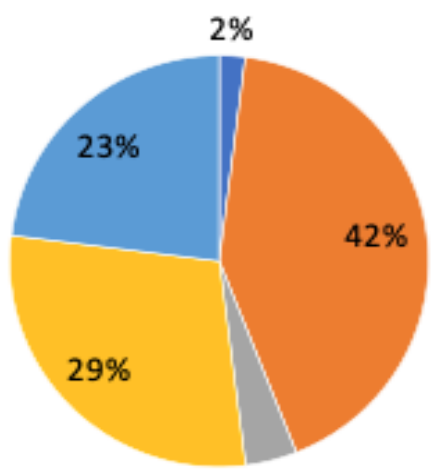

$4 \%$
[ ustening to music

$=$ Walking

$=$ Watching TV

= Playing computer games

nusing social networks

Source: authors

As a result of the study, the need for the Internet was revealed that all students use the Internet and can not imagine their life without the Internet. This is confirmed by Fig. 4.

Figura 4

The need of students of MBOU of "Secondary school

No. 19 of Chelyabinsk" for the Internet

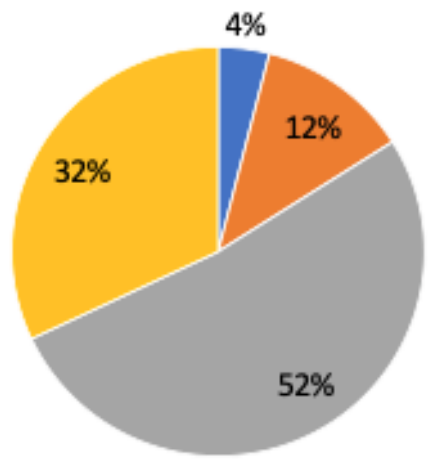

Indifferently

Deriodically there is a need to use the Internet

Daily needfor theinternet

Can not imagine my life without the Internet

Source: authors

In the course of the survey, the most significant goals of students visiting the Internet were identified. These data are presented in Fig. 5.

Figura 5

The main goals of using the Internet by students of MBOU "Secondary school No. 19 of Chelyabinsk "
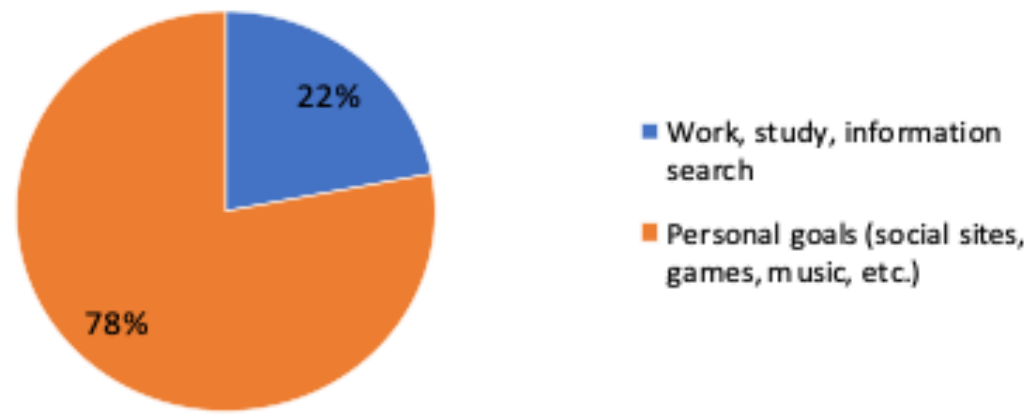

Source: authors 
After analyzing the results of students' answers to question 6 , we can conclude that the main goals of visiting the Internet are: personal goals.

One of the objectives of the study is to identify the dependence of students on social networks.

Figura 6

The number of students dependent on social networks

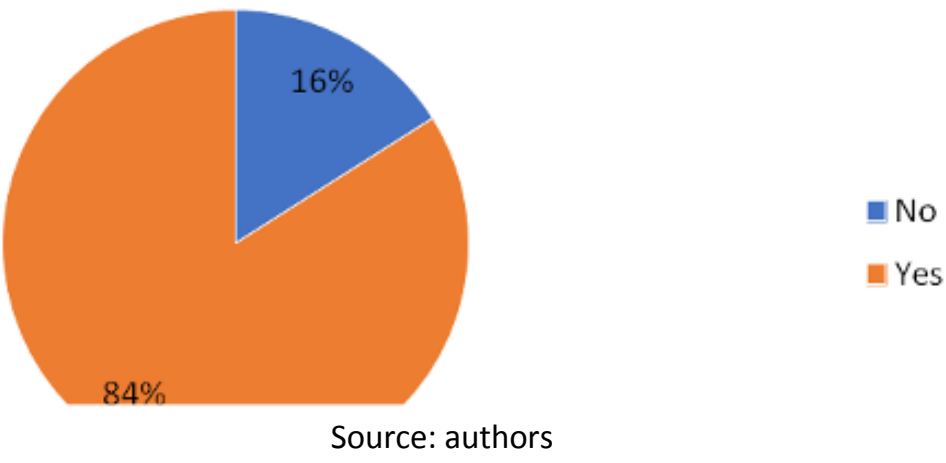

Fig. 6 shows that the vast majority of respondents (86\%) are dependent on social networks.

The social networks most often visited by students were also identified.

\section{Figura 7}

Frequently visited social networks by students of MBOU "Secondary school No. 19 of Chelyabinsk"

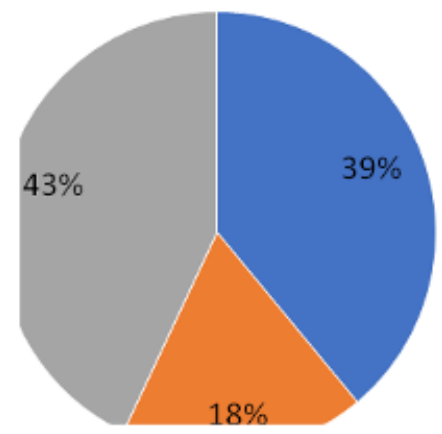

- Gaming, entertainment sites

- Searching sites

- Chat room sites

Resource: authoring

The results of answering the question allow us to draw the following conclusions: most students spend their time on sites where there is a chat room (VK, classmates, etc.), $39 \%$ of students go to gaming and entertainment sites, $18 \%$ use search sites.

The next step in the analysis of this study is to determine the level of influence of social networks on students' studies. 


\section{Figura 8}

The impact of the Internet

on students

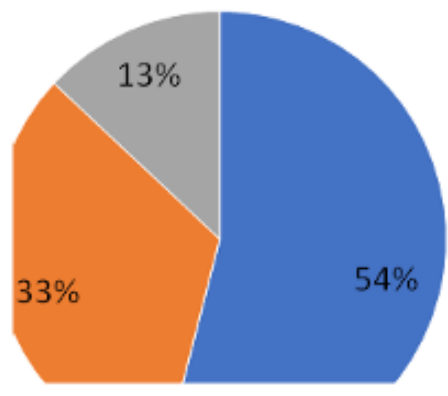

- Does not affect

- The Internet helps to study (work)

Interferes with study (work)

Resource: authoring

An analysis of the respondents' answers to question 15 showed that most students believe that the Internet does not affect the educational process (54\%), the least number of students answered that it interferes with their studies (13\%).

After conducting an experimental study of the impact of destructive online communities on students, we can conclude that most of the respondents are registered in online communities and visit them every day. Survey results showed that mainly students use the Internet for online games and communication. A significant part of students consider themselves dependent on social networks. Based on this result, it should be noted that preventive and corrective work is necessary with students and their parents.

\section{Conclusions}

Under the Internet community it is customary to understand a special type of social association of users of communication networks, the integration of which arises on the basis of a common discourse in a virtual space with a long and emotional involvement in the communication process

The main types of online communities are: social networks; Internet paging (Instant Messaging) (ICQ, Jabber, MSN Messenger, AIM, etc.); chats, chat rooms, conferences; Email; blogs ("live magazines") (online diaries of Internet users); Web forums.

Among the peculiarities of the formation of the ability of students to resist the influences of destructive Internet communities among students, the main causes of the effects of destructive Internet communities on students were identified: lack of self-control skills, inability to independently organize their leisure time, lack of communication, lack of knowledge of the rules of the hygiene of interacting with a computer, desire to replace communication with a computer loved ones, the desire to get away from the difficulties of the real world in the virtual world, low self-esteem and self-doubt, its dependence on the opinions of others, imitation, withdrawal from reality after friends.

The solution to the problem of the impact of destructive Internet communities on students is possible through the creation of a communicative field for successful socialization of students through the organization of: employment of students; psychological support; legal education and the use of active teaching methods

\section{Discussion}

The solution to the problem of the impact of destructive Internet communities on students is possible through the creation of a communicative field for successful socialization of students through: 
- organization of employment: the work of associations on the interests of the social and humanitarian profile; active involvement of students in district events (FRC, "What? Where? When?", etc.); conducting thematic leisure evenings where students present leisure-oriented projects (dance flash mobs, competitive programs, etc.);

- organization of psychological support: conducting psychological workshops on the formation of motivations for self-knowledge "I am yesterday and I am today", "My strengths and weaknesses", "Image of I", "Journey to your Self"; conducting psychological workshops on the development of emotional intelligence and the communicative sphere "I + YOU = WE", "Our common history", "First steps into adulthood. How to find a common language with a roommate "," The art of seeing and understanding others ";

- organization of legal education: conducting legal workshops aimed at preventing Internet recruitment and virtual extremism: "Internet friend or foe?", "Rules for safe Internet behavior", "Internet communities: tolerant behavior skills", "Internet communities : destructive cults, organizations, subcultures "," How not to become a victim of crime "," Dangerous situations: polite refusal "; conducting legal workshops aimed at preventing the use of profanity when communicating on the Internet: "Conflicts on the Internet and ways to overcome them", "Culture of communication on the Internet", "Administrative and criminal liability of students when communicating on the Internet", "The art of everyday communication "," Internet: jokes or hooliganism? "; conducting legal and psychological workshops, classes with training elements aimed at developing the skills of finding friends and acquaintances in social networks: "Internet communities: where do real friends live?", "Internet friends: who are you really?", "I and my environment ";

- the organization of the educational process using active teaching methods: conducting flash events "Rays of Life", "Positive Announcements", "Take Yourselves for Good Luck"; carrying out actions that form socially significant behavior; conducting discussions on the topics: "Computer: Pros and Cons", "Is computer hobby useful or harmful?", "Internet is confusion or web?", "Internet addiction is it a disease or not?", "Internet is a monster or best friend and adviser?"

\section{Bibliographic references}

Adults and children in the digital world: when online meets offline. Retrieved from: https://kids.kaspersky.ru/wp-content/uploads/sites/2/2019/04/190402_Children_Russia_Report_Practics1.pdf

Child safety on the Internet. Retrieved from: https://www.ifap.ru/library/book099.pdf

Child Safety Online. Global challenges and strategies. 2012 Retrieved from: https://www.unicefirc.org/publications/pdf/ict_techreport3_eng.pdf

Children in the digital world. Retrieved from: https://www.unicef.org/eca/media/4926/file/\%D0\%A0\%D0\%B5\%D0\%B7\%D1\%8E\%D0\%BC\%D0\%B5\%D0\%94\%D0\%B5\%D1\%82\%D0\%B8-\%D0\%B2\%D1\%86\%D0\%B8\%D1\%84\%D1\%80\%D0\%BE\%D0\%B2\%D0\%BE\%D0\%BC\%D0\%BC\%D0\%B8\%D1\%80\%D0\%B5-2017-\%D0\%AE\%D0\%9D\%D0\%98\%D0\%A1\%D0\%95\%D0\%A4.pdf

Ferranti S. (2016). How screen addiction is damaging kids' brains. VICE. Retrievedfrom: https://www.vice.com/en_us/article/5gqb5d/how-screen-addiction-is-ruining-the-brains-of-children

Global kids online research toolkit. Retrievedfrom: http://globalkidsonline.net/wpcontent/uploads/2016/04/Survey-toolkit-guide-revised-May-2020.pdf 
Jane Timmons-Mitchell, Deborah A. Levesque, Leon A. Harris, III, Daniel J. Flannery, Tatiana Falcone, Pilot Test of StandUp, an Online School-Based Bullying Prevention Program, Children \& Schools, Volume 38, Issue 2, April 2016, 71-79, https://doi.org/10.1093/cs/cdw010

Kardaras N. (2016). It's 'digital heroin': How screens turn kids into psychotic junkies.New York Post. Retrieved from: https://nypost.com/2016/08/27/its-digital-heroin-how-screens-turn-kids-into-psychotic-junkies/

Nutt D. J. et al. (2015)The dopamine theory of addiction: 40 years of highs and lows. Nature Reviews Neuroscience, T. 16, 5, 305-312.

Sergodeev V.A. (2013) Network Internet communities: essence and sociocultural characteristics // Bulletin of the Adygea State University. Ser .: Regional studies: philosophy, history, sociology, jurisprudence, political science, cultural science, 1,122-127.

Esta obra está bajo una Licencia Creative Commons Attribución-NoCommercial 4.0 International

(cc) BY-NC 